\title{
A Paradigm Shift for Innovation and Creativity in Africa in the $21^{\text {st }}$ Century
}

\author{
JUSTUS M MUNYOKI, PHD \\ University of Nairobi, School of Business, P.O. Box 30197-00100, NAIROBI, Kenya
}

\begin{abstract}
Innovation has for many years been associated with growth and development of organizations and nations. Creativity is closely associated with innovativeness and indeed, without creativity there can be no meaningful innovativeness. The developed world has been associated with innovativeness for many decades, long before there was anything meaningful in the Developing world such as the African Continent .Thus, most inventions that we know today came from the developed world. Using a narrative and descriptive approach of the past and the present trends in both the developed and the African continent, the author seeks to demonstrate that in spite of the myriad of challenges, innovation and creativity are driving economic development in Africa and will continue to do so in the $21^{\text {st }}$ century. Africa is on the rise and holds the future in terms of innovation and creativity, and will shape the $21^{\text {st }}$ century as far as innovation and creativity is concerned. Africa has the potential and the capacity to host the innovations of the $21^{\text {st }}$ century and beyond, just as Europe hosted the industrial revolution in the $19^{\text {th }}$ century. The author argues that with a young growing population with a huge untapped natural resources, Africa presents the best opportunity for creativity and innovativeness in the $21^{\text {st }}$ century. The author is cognizant to the fact that Africa is very diverse and cannot be lumped together as one big entity, but recognizes that a majority of the countries therein suffer the same challenges, which will be the main triggers to creativity and innovation in the $21^{\text {st }}$ century Keywords: innovativeness, Creativity, economic development, African continent
\end{abstract}

DOI: $10.7176 / \mathrm{EJBM} / 11-21-01$

Publication date:July $31^{\text {st }} 2019$

\section{Introduction}

Innovation is a term used to imply newness, new ideas, or processes, and is therefore about value addition in products. Innovation leads to development of new ideas and processes and has over the years been associated with growth and development especially in the developed world. Historically, countries in Europe are known to have come up with very may innovation and inventions that shaped the world. The aircraft that we use today, the motor cars, the cameras, the computers, and nearly everything used today came from the developed world. Surbhi (2016) argues that invention is about the creation of a brand new product or device, while Conversely, innovation is an act of making changes to the existing product or the process by introducing new ways or ideas. This means that innovation comes as way of improving onto an existing invention. Invention is about 'An original idea and its working in theory', while innovation as a concept focuses on 'Practical implementation of new idea' Surbhi (2016,pp 2).

The end of the second world war marked a new beginning in countries like Japan that found themselves in an awkward position as they had been ravaged by the world war. German too, was totally destroyed by the war. This made the countries think hard and come up with creative and innovative ways of rebuilding their economies. Germany went into car manufacturing while Japan too stated to make automobiles as a survival tactic. As this was happening, Africa very little was happening in Africa, in spite of the huge untapped resources and a young population. Whatever was in terms of innovation and creativity was too traditional and insignificant to make any meaningful impact in the world. But the world wars had exposed Africans to the rest of the world as they took part in the war in different parts of the world. This in a way helped to make Africans see how others were making do with much less resources that Africa

Innovation in many cases is triggered by the presence of major challenges that a firm wants to address. These include lack of physical resources such as land, shortage of qualified human resources, or financial resources , increased competition, poverty and so on can make an individual of or an organization come up with innovative way of dealing with the challenges. With these challenges being very apparent in most parts of Africa, then the need for innovation and creativity is more dire than in any other part of the world. The Organization for Economic Cooperation and Development (OECD), define an innovation as 'The implementation of a new or significantly improved product, a new process, a new marketing method, or a new organizational method in business practices, workplace, organization, or external relations. OECD identifies four types of innovation:

- Product innovation: This is about new or improved goods and services. The idea behind product innovation is to enhance efficiency in the way a product is used. Thus improvements in technical specifications or additional software that makes the product more user friendly may be regarded as product innovation. We would like to present evidence product innovations Africa

- Process innovation: According to OECD, implementation of a new or significantly improved production 
or delivery method in a way that it enhances service delivery constitutes process innovation.

- Marketing innovation: this occurs in situations in which there are significant improvements in the marketing programs in terms of changes in product design or packaging, product placement, product promotion or pricing.

- Organizational innovation: This involves implementation of a new organizational method in the firm's business practices, workplace organization or external relations. It may be seen as improvement of systems within an organizational structure in a way that there is enhanced service delivery

All these forms of innovation are important and in any given context, they may take place simultaneously but often with one being more dominant than the rest. They are all important in the growth and development of any country. This study seeks to determine what kind of innovation is likely to dominate Africa in the $21^{\text {st }}$ century. Perhaps what we need to ask is "what kind of technology is likely to dominate the African continent?.

\section{Methodology}

The researcher has relied on a thorough review of existing literature regarding what has been documented about creativity and innovation in various parts of the world. The study adopts and exploratory and narrative approach to bring about documentary evidence on what has been happening across the globe regarding creativity and innovation. Exploratory designs are suitable in a study like this one in which there is no clear population or unit of analysis and the researcher thus relies on his judgment and experience regarding the selection of relevant literature sources that provide the necessary data. The Narrative approach enables the researcher to bring about deeper insights about the research area, and opens up ground for further investigations. The study relies on review of existing literature to trace the origins of innovation and creativity across the grove, and uses this evidence to relate with specific developments in Africa. The methodology is suitable in studies whose aim is to prove evidence of existence of a practice as is the case with this study. The study thus synthesizes the evidence from the literature to show that in deed creativity and innovation have been taking place in Africa, and that Africa is is in the best position to take the lead in terms of innovation during the $21^{\text {st }}$ century

\section{Literature Review}

Innovation is a concept that implies newness, or simply coming up with anything that is perceived as new. There is plenty of literature about innovation has been building over the years, and both academicians and theorists put innovation as a very important concept It is a result of creativity. Surbhi (2016) defines invention as the creation of a brand new product or device, while innovation is the act of making changes to the existing product or the process by introducing new ways or ideas. As a concept, invention refers to an original idea and its working in theory, while innovation is about practical implementation of new idea. Thus although innovation and invention seem to have certain common features, they are very different terminologies. Once a product has been invented as a novel product that has never existed before, this will be an invention, and other improvements will continue to be made to respond to different situations, and all these are innovations. The first time a wheel was developed, it was an invention. However, many other forms of wheels have been made over the years, and all constitute innovations and not inventions 'You cannot reinvent the wheel'.

There have been arguments and counter arguments in terms whether or not Africa has been doing any innovations, but even though Africa has a very rich history as the cradle of human history, we cannot really talk about serious innovations in the continent. It has been argued that Africans were for many years involved in some kind of innovations, such as making of stone and iron tools for hunting, these are really very traditional and low level technologies, nothing compared to what was happening in Europe and in other developed countries. We can however, argue that although many inventions took place in the developed world, there are today many innovations taking place in Africa.

PhilMckinney (2016) argues that Innovation in Africa suffers major drawbacks due to certain limitations which include access to capital, poor technical manpower, legal systems and inadequate infrastructure. African governments need to take these as key priority areas in the 21 stcentury, if the potential in Africa is to be fully tapped and bring about the desired innovation in Africa. In Africa, there is limited access to capital that is very important for investment, and most countries have to turn to financial institutions and other donor agencies, which increases the debt burden. Countries like China have now invaded Africa in a very big way, initiating projects especially in infrastructure, but this continues to increase the debt burden to the countries that are already too poor to sustain meaningful development. African countries thus need to focus on investments that bring about innovations. Another bottleneck is that of infrastructure. Good infrastructure implies that movements of goods and services is faster. It implies that businesses have more time to think about innovative ways of doing things. It means efficiency in service delivery. However, poor infrastructure which characterizes many African countries makes it difficult for companies to spare resources and innovate. The legal frameworks in a number of African countries does not support innovations. There are many bureaucratic bottlenecks that make it very difficult for those with innovative ideas to nurture them. Issues of registration, copyrights and uncoordinated procedures make 
it very frustrating to those who want to innovate. The challenges posed here should act as the antecedents to innovation and creativity in Africa, otherwise Africa will remain undeveloped. They act as the triggers that should cause major technological disruptions in Africa during the $21^{\text {st }}$ century. But innovation is not just about technology. There are very many ways in which innovation can take place without being associated with technology. For instance, innovative ways of managing time, serving customers better, and relating well with members of the society are innovations that are not technology based. Organizations need to come up with innovative ways of quality customer delivery, dealing with customers.

Evans (2017) discusses 11 innovations that changes history, due to the impact that they had in the world. These include the printing press (Developed in Germany, initially as the Gutenberg's machine 1440). This allowed for the rapid production of lead alloy type pieces, and greatly increased the production of affordable books as it could make as many as 3,600 pages per day. The second major innovation was the compass (originally invented in China, and by the 14th century and proved very useful during the age of exploration as provided direction to explorers who were moving around the world). Paper currency, widely used in China in the ninth century, before it appeared in Europe in the late 1600s, was the third manor innovation. It replaced the use of precious metals as money and made it much more convenient to do business. The fourth major innovation is steel, which, although its use goes back to 4,000 years, experienced mass production of alloy was initiated through the Bessemer process, a technique for creating steel using molten pig iron, in the 1850s. This made Steel explode into one of the biggest industries on the planet and was used in the creation of everything from bridges and railroads to skyscrapers and engines.

Electric light is listed as the fifth major innovation, pineered in the early 19th century by Humphry Davy through his carbon arc lamp, while Edison and Swan patented the first long-lasting light bulbs in 1879 and 1880 , liberating society from a near-total reliance on daylight. Domestication of the horse, which was done about 5,500 years ago is the sixth major innovation, and enabled people to travel great distances and interact with other people of different cultures and facilitated trade across different regions. The seventh major innovation was the introduction of transistors, first developed in 1947 by Bell Laboratories. These allowed for precise control of the amount and flow of current through circuit boards. The semiconductor devices have continued to shape the world today through their application in nearly all electrical devices such as radios, televisions, cell phones and computers. Magnifying lenses, which first came into use in the 13th century as an aid for the weak-sighted, became the $8^{\text {th }}$ major innovation, through the introduction of the first microscopes and telescopes in the late 16th and early 17 th centuries. Galileo Galilei and Johannes Kepler later employed the telescope to chart Earth's place in the cosmos. Magnifying lenses have since led to new breakthroughs in an abundance of fields including astronomy, biology, archeology, optometry and surgery.

The ninth major innovation is the telegraph (widely used in the $19^{\text {th }}$ century) to, but the original telegraph and its wireless successors went on to be the first major advancements in worldwide communication and the ability to send messages rapidly across great distances greatly enhances government and business operations. The tenth major innovation is the introduction of antibiotics. The introduction of antibiotics was a great invention in the field of medicine, and saved millions of lives by killing and preventing the growth of harmful bacteria. This was pioneered by Louis Pasteur and Joseph Lister in their attempt to combat bacteria, but it was Alexander Fleming who made the first leap in antibiotics when he accidentally discovered the bacteria-inhibiting mold known as penicillin in 1928. The last major innovation is the Steam Engine, Thomas Savery developed the first a steampowered water pump in 1698, which paved the way for perfection of steam engines in the late 1700s by James Watt. They became very instrumental during the Industrial Revolution. What these great invention suggest is that scientists and other researchers have been doing inventing for many years. There are many more inventions that are not mentioned in this list, and these only serve as an indication of what has been happening over the years. However, what comes out is that all these were happening in other parts of the world and none of them come from Africa.

Considering growth in Knowledge in the form of adult education, OECD, which defines a country's adult education level as the percentage of people between the ages of 25 and 64 who have completed some kind of tertiary education in the form of a two-year degree, four-year degree or vocational program, lists the 10 top most educated countries as Canada (56.27\%), Japan $\quad(50.50 \%)$, Israel $\quad(49.90 \%)$, Korea (46.86\%), United Kingdom (45.96\%), United States (45.67\%), Australia ( $43.74 \%$ ), Finland (43.60 \% ), Norway (43.02\%), and Luxembourg ( $42.86 \%$ ). Again, none of these countries is in Africa!. Similarly, the World Economic Forum's latest Global Competitiveness Index lists Switzerland is the world's most innovative country, followed by the US and Israel in that order. The other highly innovative countries are Finland, Germany, Netherlands, Sweden and Denmark, all in Europe, while the last two among the top ten are Japan (eighth) and Singapore (ninth).Japan scores highest in patent applications while Singapore is strong on government investment in advanced technology products. Thus when we look at knowledge and Innovation, all the top countries in the world are in the developed world, where there is also the highest level of innovation. None of these countries is in Africa. Africa as a continent experiences many challenges and may therefore not be able to move as fast as the developed economies. However, 
there is every indication that Africa is in the right track and will possibly start featuring among the world most innovative countries of the world in the next 50 years. This is an indication that Africa is lagging behind in knowledge. What is evident is that in the $19^{\text {th }}$ century, while Europe was going through the industrial revolution, Africa had very little to show, there were very few universities in Africa, perhaps in northern Africa like Egypt and South Africa. Without knowledge, it was tall order to expect any meaningful innovations to take place in those countries

Whereas not much is said about Africa, there is evidence that a lot was happening for many years in Africa. In fact, mathematics and other numerical computations were done in Africa for thousands of years (Sydella 2013). According to Zaslavsky, (1983), the Egyptians scripted textbooks about math that included division and multiplication of fractions and geometric formulas to calculate the area and volume of shapes for than 35,000 years ago. (Sydella (2013), further points out that the Yoruba had also a system of carrying out computations, based on units of 20 (instead of 10), which has been praised by scholars as it required much abstract reasoning Zaslavsky, (1983) C. "The Yoruba Number System.” Blacks in Science: Ancient and Modern. 110 -127,(1983).

There is also evidence of ancient astronomy in Africa, for example, the Egyptians came up with some kind of calendar in which they divided the year into 12 parts and developed a yearlong calendar system containing 365 $1 / 4$ days Woods, (1988). Sydella 2013 also argues that Ancient Africa was for many years involved in Metallurgy and tools which included steam engines, metal chisels and saws, copper and iron tools and weapons, nails, glue, carbon steel and bronze weapons and art Brooks, (1971. In fact, advances in Tanzania, Rwanda and Uganda between 1,500 and 2,000 years ago surpassed those of Europeans, for instance, ancient Tanzanian furnaces could reach $1,800^{\circ} \mathrm{C}-200$ to $400^{\circ} \mathrm{C}$ warmer than those of the Romans Shore,. (1983). Africa also made major advances in the field of medicine, by using extractions from trees and performing many medical procedures such as vaccination, limb traction and broken bone setting.

What these tell us is that a lot had been happening in Africa even as Europe and other parts of the developed world were inventing. Perhaps what is different is the scale of operation, in that in Africa, much of what was happening was confined to a few isolated parts, without transfer to other parts of the world, leave alone Africa. There was very little technology transfer in Africa at the time, and hence very little of what was happening found its way to other parts of the world.

In Africa, there is generally low knowledge levels, this is fast changing and we now have many universities that have now enabled many Africans to go to university. Kenya, for example, the number of universities has more than doubled in the last twenty years, with the number of students enrolled in universities stranding at over 500,000. Ghana has in the last five years been working towards converting some of their polytechnics to Universities of applied sciences. As such, there is likelihood of more innovations coming out of the African continent. Knowledge is related to innovations and countries that have accumulated a large pool of knowledge base are likely to experience a higher level of creativity and innovation than one that has a low level of innovation.

The World Bank has come up with key initiatives that help to promote knowledge transformation in African. Through the initiative aims at promoting economic transformation across Africa by supporting African policymakers to make better use of evidence and knowledge. It seeks to support scholars and African Governments to enhance the uptake of cutting-edge research and evidence in order to support more informed economic policy making. This initiative recognizes Africa as a knowledge-based continent driven by its own citizens and representing a dynamic labor force in the global arena. Thus the initiative is a clear indication that Africa is on the rise as a source of knowledge.

\section{Findings}

This study has established that although little is documented in Africa, creativity and innovation have been taking place for many years, the only difference being that what has been taking place in Africa has been too little to have any meaningful global impact. Africa, education levels are still low, yet knowledge and innovation go hand to hand. There is evidence that a lot of product innovations are taking place in Africa. Naadiva (2016) ponders the question 'Is Africa leading the innovation revolution?' and goes on to demonstrate that indeed, with the accelerated growth in technology in areas such as mobile use, improved infrastructure and accelerated population growth, Africa is poised to lead in innovation in the coming years. Indeed, the mobile phone in Africa has become a gamechanger for the continent and according to Ericsson, the technology company, by 2019 there will be 930 million mobile phones in Africa, almost one for every person on the continent.

The second finding is that Africa has a very high percentage of young population with a big potential to innovate. PhilMckinney (2016) quote Forbes article that states: ... there is a rising number of young Africans who are building fast-growing companies in food manufacturing, engineering, technology, hospitality, and any other industry you can think of. They are creating jobs, paying taxes, igniting the entrepreneurial spark amongst their contemporaries, and ultimately, playing pivotal roles in the continent's renaissance. You can't ignore them anymore'

This assertion is very correct. Africa has over $25 \%$ of its population aged below 25 years, and population 
growth rate at over $2 \%$ is among the highest in the world. This is a strong indication that there is a lot of potential in Africa. The United Nations reports that Africa has the highest rate of population growth, growing at a pace of 2.55 per cent annually in 2010-2015. This is in contrast with developed countries like Europe in which Several countries are expected to see their populations decline by more than 15 per cent by 2050 (http://www.un.org/en/sections/issues-depth/population/). It is projected that by 2050, Africa will account for more than half of global population growth. This provides a major opportunity for Africa, as it will have a large pool of working people who can contribute heavily towards innovation. The large population will itself be a challenge as it will mean constrains in resource allocation. With the burden of large populations, then African countries will have no choice but to innovate in order to sustain their growing populations

Of the four areas of innovation, this article proves some evidence on innovation and the huge potential therein. Considering product innovation, Africa needs product innovations in terms of coming up with improved products and advanced the way: Africa needs more improved products especially in the area of energy and ICT. Andy (2017), argues that despite the challenges facing Africa, there are early signs that Africa is on the right track towards an innovation revolution. For instance, Africa is home to five of the 10 nations that have the most startups. These include Ghana, Kenya, Nigeria, Morocco, Senegal and South Africa. Intake of smartphone across Africa is also very high and is set to increase. Andy (2017) states that between 2014 and 2016, the number of smartphone connections across the continent doubled to 226 million while the cost of a smartphone dropped from an average of $\$ 230$ in 2012 to $\$ 160$ in 2015 . Africa is doubtlessly the fastest-growing mobile phone market in the world, and is according to a 2016 report by the Global System for Mobile Communications Association as cited by Mourdoukoutas (2017), Africa will have 725 million smartphone users by 2020. The reason for this is because the mobile phone is used to facilitate access to the internet. In Kenya, we have people working in the informal sector with very innovative ways of making their products. These include energy saving jikos, wheel barrows and boilers. The informal sector, commonly called the jua kali sector, has thus become a major source of employment for the youth in Kenya . Some of the products made innovatively in Kenya and Ghana are shown in Figure 1and 2

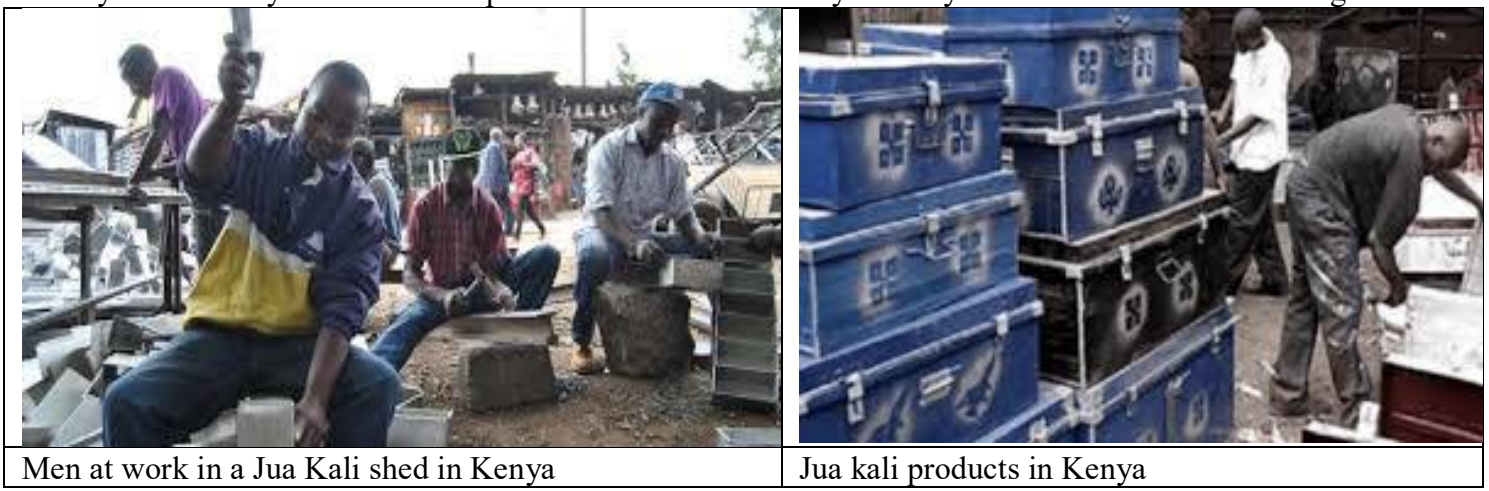

Figure 1: Men at work and Jua kali products in Kenya

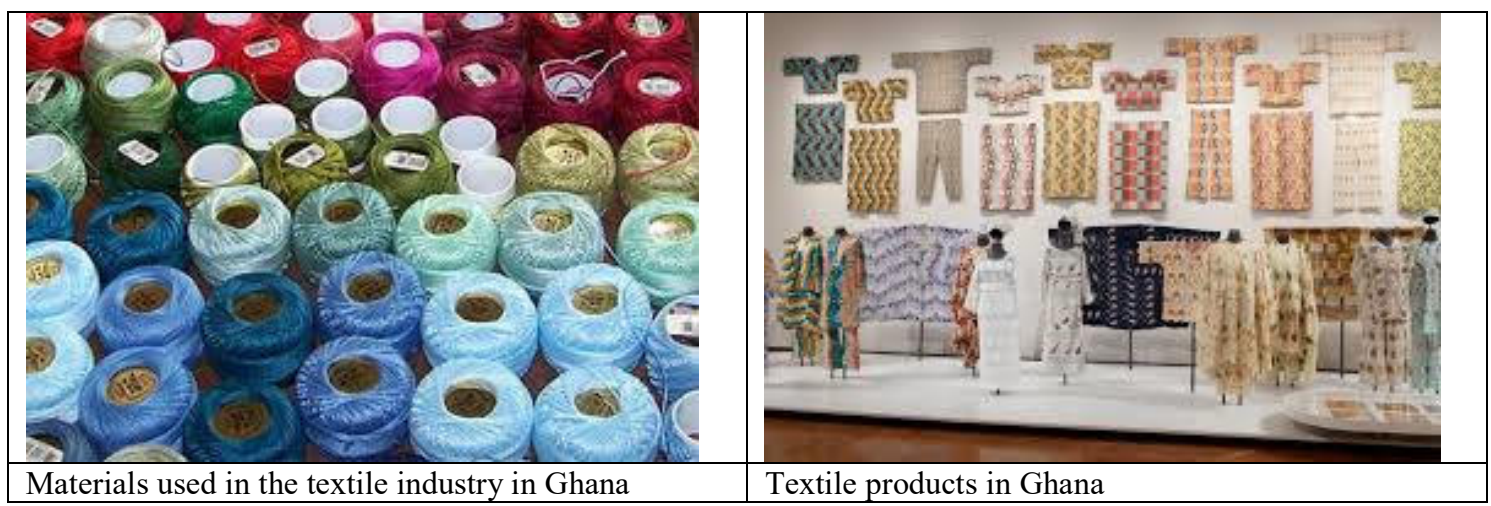

Figure 2: Textile materials and products in Ghana

In terms of process innovation, we find that processes in Africa are still low in terms of technological advancement. In a number of situations, processes are still manual rather than electronic, which slows down processes. In Kenya, for example, use of biometric systems in carrying out national elections in 2013 and 2017 has been hailed as a great success, but this was technology imported from the developed countries. Process innovations is an area that will continue to attract a lot of attention in Africa. Mobile phones together with increased Internet access have made it possible for governments to put their services online and digitize their 
records. Rwanda has for the past 15 years been working to digitize its education, health care and economy, and it is currently pushing to be Africa's first cashless society in the public sector; it is already paying its government employees electronically. But Rwanda is not alone in this. Other countries like Kenya and Ghana are also moving in the same direction. The introduction of Huduma centres by the government of Kenya to serve customers may be seen to be a great innovation which has greatly improved service delivery by the government to its citizens. Figure 3 shows citizens within a Huduma Services Hall in Kenya.

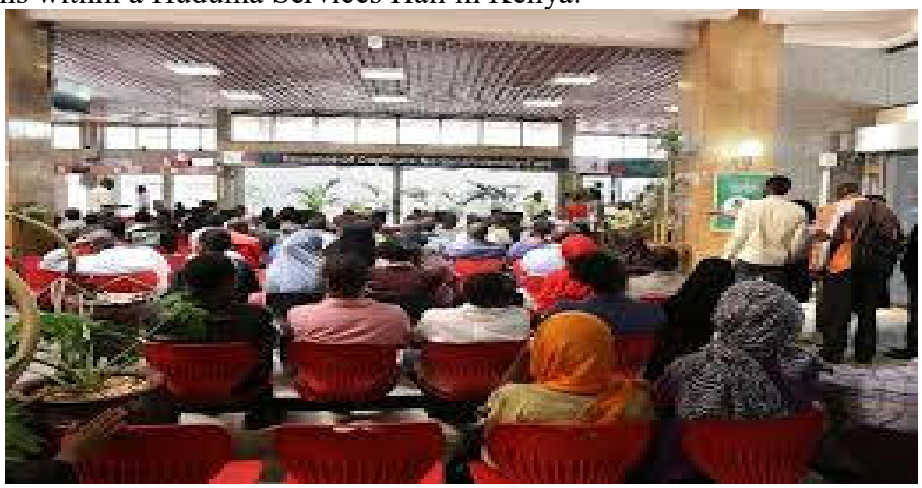

Figure 3. Citizens getting services at a Huduma centre in Kenya

As of marketing innovation, Africa will need to focus on improvements in the marketing in terms of changes in product design, packaging, product placement, product promotion or pricing. There is evidence of innovations taking place in Africa in terms of product packaging, designs and promotion. Packaging like production of user friendly packaging materials. Most of marketing innovation is internet aided and over the years, entrepreneurs and other business people have used technology to innovatively market their products all over the world,

Finally, organizational innovation is and will continue to attracting innovations in organizational structures in order to become more responsive to customer needs and improve service delivery. : This is further evidence that a lot is happening in Africa. Innovation is taking place in all the areas of innovation, particularly in the area of product innovation, process innovation and marketing innovation.

\section{Conclusion}

From the discussion, it is clear that innovations and creativity are almost as old as human kind, and these have continued to shape human behavoiur and the world over the years. However, the rate of innovations has been faster in the developed world than in the developing world. Most of the innovations we have today came from Europe, although there is evidence that other parts of the world such as China also were also inventing. Africa, too had their own inventions, but they were rather insignificant and did not have world wide impact because of their scale of production. Things like stone tools, bows and arrows that were made by Africans could only impact a community and not an entire nation. Traditional medicine from Africa was very potent, yet it is very less talked about.

\section{Implications}

This study has major implications to African countries as it brings to the fore the fact that African countries have not done enough to exploit what they already have. The author has demonstrated that in spite of the many challenges that Africa has faced, a lot has been happening, sometimes for much longer than in the developed world. The difference was that while the other parts of the world went out to market what they have thought technology transfer, Africa remained largely a closed continent, until the period of European exploration. African countries need to move faster than before, correct the mistakes of the past, and move into the innovation revolution that is bound to take place in Africa during the $21^{\text {st }}$ century.

The study seeks to place Africa in its rightful position of leadership in innovations and creativity. To do this African countries will need to try and stand on themselves rather than always turning to the developed countries for support. The paper clearly demonstrates that constraints that are evident in Africa should act as a catalyst for acceleration in terms of innovation. The solution lies in being innovative and not in going for hand outs and support from the developed countries. Africa needs to tap into its largely untapped potential in terms of unutilized or underutilized resources and use these as the springboard towards greater innovation and creativity.

\section{Recommendations}

This study recommends that there is a great need to properly document the technological developments and advances taking place in Africa, so that the overall impact of innovations in Africa may be exploited. This will help the world to clearly appreciate where Africa has come from and her present situation. This will also help to 
remove the notion that everything happening in Africa came from the developed world. Proper documentation will also help to bring out the various innovations that have existed in Africa for many years, then determine which innovations can be up scaled to global level.

The researcher recommends that African countries need to set aside higher budgets for research and development in order to enable researchers to carry out research and come up with innovations that can shape the world and put Africa in its rightful place in terms of innovations. Funding for research should be a deliberate effort by all countries in Africa. Without adequate funding especially in the institutions of higher learning, many countries in Africa will continue to suffer from low levels on innovation. The need for institutions of higher learning to consider and provide more funding to researchers to carry out relevant research and come up with innovations is overwhelming.

The final recommendation is about university industry collaborations and partnerships. Forging strong university industry collaborations will help institutions of higher learning to understand the industry in a more practical way, and know areas where innovations are required. This will also enable industry players to understand what universities are doing and perhaps even support some of the ideas that can be developed further into practical innovations.

Finally, this study has dwelled more on qualitative narratives about the state on innovation and creativity in Africa. The researcher therefore recommends a more structured empirical study to determine the extent to which Africa is innovating. This will generate more quantitative data on specific indicators of innovation.

\section{REFERENCES}

Phil McKinney (2016); Innovation in Africa: Challenges and Opportunities - $\mathrm{h} t t p s: / / p h i l m c k i n n e y . c o m / i n n o v a t i o n-$ africa-challenges-opportunities/

Surbhi S (2016); Difference Between Invention and Innovation.

https://keydifferences.com/difference-between-invention-and-innovation.html

Naadiya M 2016 Is Africa leading the innovation revolution?

https://www.weforum.org/agenda/2016/01/is-africa-leading-the-innovation-revolution/

Think Africa Partnership: A Knowledge Platform for Economic Transformation and Growth in Africa .https://www.worldbank.org/.../think-africa-partnership-a-knowledge-platform-for-eco

Brooks, L. (1971), African Achievements: Leaders, Civilizations and Cultures of Ancient Africa.

Andy B 2017 "Africa needs an innovation revolution - here's how it can happen". https://www.weforum.org/agenda/2017/05/africa-needs-an-innovation-revolution-here-s-how-it-canhappen/

Evan A Dec 18, 2012 . 11 Innovations That Changed History. https://www.history.com/news/11-innovations-thatchanged-history, Dec 18, 2012

Sydella (2013) Great achievements in science and technology in ancient Africa, ASBMB, Woods, G. (1988). Science in Ancient Egypt

Zaslavsky, C (1983) . "The Yoruba Number System." Blacks in Science: Ancient and Modern. 110 - 127

Shore, D. (1983) "Steel-Making in Ancient Africa." Blacks in Science: Ancient and Modern.157 - 162 (1983).Andy B 2017. Africa needs an innovation revolution

https://www.weforum.org/agenda/2017/05/africa-needs-an-innovation-revolution-here-s-how-it-can-happen/

Mourdoukoutas E (2017); Africa's digital rise hooked on innovation. Africa renewal: https://www.un.org/africarenewal/magazine/may-july-2017/africa\%E2\%80\%99s-digital-risehooked-innovation 